\title{
Influence of spacer chain lengths and polar terminal groups on the mesomorphic properties of tethered 5-phenylpyrimidines
}

\author{
Gundula F. Starkulla ${ }^{1}$, Elisabeth Kapatsina ${ }^{1}$, Angelika Baro ${ }^{1}$, \\ Frank Giesselmann ${ }^{2}$, Stefan Tussetschläger ${ }^{1}$, Martin Kaller ${ }^{1}$ \\ and Sabine Laschat ${ }^{* 1}$
}

\section{Full Research Paper}

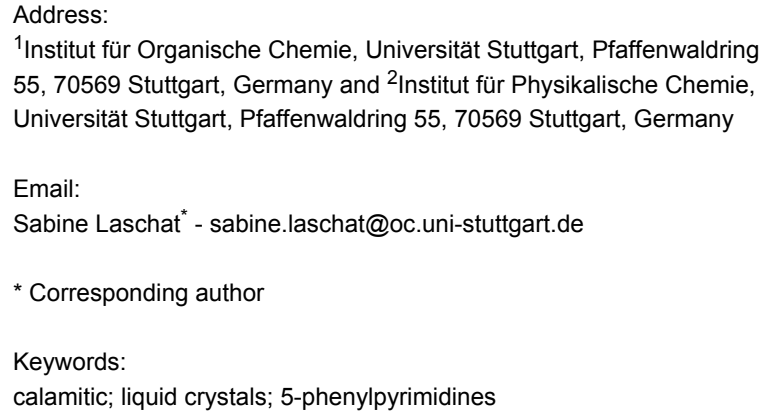

${ }^{1}$ Institut für Organische Chemie, Universität Stuttgart, Pfaffenwaldring 55, 70569 Stuttgart, Germany and ${ }^{2}$ Institut für Physikalische Chemie, Universität Stuttgart, Pfaffenwaldring 55, 70569 Stuttgart, Germany

Email:

Sabine Laschat ${ }^{\star}$ - sabine.laschat@oc.uni-stuttgart.de

* Corresponding author

Keywords:

calamitic; liquid crystals; 5-phenylpyrimidines

\author{
Beilstein Journal of Organic Chemistry 2009, 5, No. 63 \\ doi:10.3762/bjoc.5.63 \\ Received: 31 July 2009 \\ Accepted: 19 October 2009 \\ Published: 09 November 2009 \\ Guest Editor: S. Laschat \\ (c) 2009 Starkulla et al; licensee Beilstein-Institut. \\ License and terms: see end of document.
}

\begin{abstract}
Based on 5-(4-hydroxyphenyl)-2-octylpyrimidine 8, 5-phenylpyrimidine derivatives 3-7, 9 with different spacer chain lengths $\left(\mathrm{C}_{2}\right.$ up to $\left.\mathrm{C}_{6}\right)$ and different terminal polar groups $\left(\mathrm{Br}, \mathrm{Cl}, \mathrm{N}_{3}, \mathrm{OH}, \mathrm{CN}\right)$ were synthesized by etherification and nucleophilic substitution. The mesomorphic behaviour of these compounds was investigated by differential scanning calorimetry (DSC), polarizing optical microscopy (POM) and X-ray diffraction (WAXS and SAXS) and revealed smectic A mesophases for bromides, chlorides and azides 3, 4 and 6. For these compounds a maximum phase width was observed for the $\mathrm{C}_{5}$ spacer regardless of the terminal group, whereas the hydroxy- and cyano-substituted derivatives 5 and 7, respectively, were non mesomorphic and showed only melting transitions.
\end{abstract}

\section{Introduction}

A tremendous amount of work has been done on calamitic liquid crystals, which has led to applications in the field of LC displays [1]. Among the large family of various calamitic mesogens 2-alkoxy-5-phenylpyrimidines $\mathbf{1}$ are prominent members due to the fact that the two nitrogen atoms increase the polarity of the rigid rod core structure (Scheme 1) as exemplified by the derivative 1a which displays a SmA phase between $45^{\circ} \mathrm{C}$ and
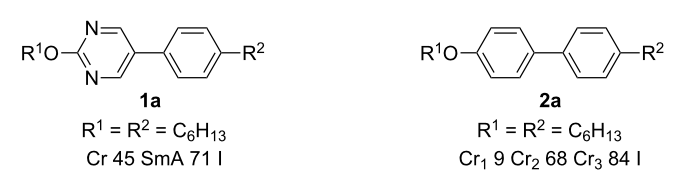

Scheme 1: Comparison of mesomorphic properties of $\mathbf{1 a}$ and $\mathbf{2 a}$. 
$71^{\circ} \mathrm{C}$, while the corresponding biphenyl derivative $2 \mathrm{a}$ with the same terminal alkyl chains does not have any liquid crystallinity [1].

Whereas three regioisomeric phenylpyrimidines are possible i.e. 4-, 5-, and 2-phenylpyrimidine, only the latter two are suitable for liquid crystals. Furthermore 5- and 2-phenylpyrimidines differ in their overall conformation. According to ab initio calculation by Barone [2], 2-phenylpyrimidine is almost planar, whereas 5-phenylpyrimidine has a twisted conformation with a dihedral angle of $43.1^{\circ}$ [3]. The different conformations together with differences of the polarisation and dipole moment between 2- and 5-phenylpyrimidines also lead to different mesomorphic properties as was shown by Lemieux for phenylpyrimidines tethered to terminal trisiloxanes $[4,5]$ and by Tschierske for dimeric phenylpyrimidines tethered to oligoethyleneglycol units [6].

We recently reported the synthesis of $1,1^{\prime}$-biisoquinolines tethered to calamitic subunits [7]. During these studies we discovered that the 5-phenylpyrimidine building block $3 \mathbf{e}$ already displayed a SmA mesophase. We thus wondered whether variation of the spacer chain lengths and terminal group X (Scheme 2) might have significant influence on the mesomorphism. The results of this study are discussed below.

\section{Results and Discussion}

Syntheses: In order to obtain different series 3-7 the known 5-(4-hydroxyphenyl)-2-octylpyrimidine 8 [7-12] was used as starting material (Scheme 3).

Compound 8 was deprotonated with $\mathrm{KOH}$ in DMSO at room temperature for $10 \mathrm{~min}$ followed by addition of 1, $\omega$-dibromoalkane. After $4 \mathrm{~h}$, the reaction mixtures were purified and the desired bromides $\mathbf{3 b}-\mathbf{e}$ were isolated in 23 up to $60 \%$ yield. When 1,3-dibromopropane was used, $27 \%$ of the elimination product 9 was isolated as byproduct. For comparison the corresponding 4-allyloxy-4'-octylbiphenyl 11 was prepared in 49\% yield by allylation of 4-hydroxy-4'-octylbiphenyl. Compound 3a was obtained by etherification of 5-(4-hydroxyphenyl)-2- octylpyrimidine 8 using $\mathrm{K}_{2} \mathrm{CO}_{3}$ in $\mathrm{MeCN}$ under reflux for $12 \mathrm{~h}$ to yield $39 \%$. The synthesis of series $\mathbf{4}$ with chloride as terminal group proceeded in a similar way by using $1, \omega$-dichloroalkanes giving $4 \mathbf{a}-\mathbf{e}$ in $31-70 \%$ yield. Upon deprotonation of $\mathbf{8}$ under the conditions described above, followed by treatment with 5-bromopentanol or 6-bromohexanol, the hydroxy compounds 5d and 5e were isolated in $76 \%$ and $80 \%$ yield, respectively. To obtain the azides $\mathbf{6}$, bromides $\mathbf{3 a}-\mathbf{e}$ were treated with $\mathrm{NaN}_{3}$ in $\mathrm{DMF}$ at $100{ }^{\circ} \mathrm{C}$ for $24 \mathrm{~h}$ and the products $6 \mathbf{a}-\mathbf{e}$ were isolated in $74 \%$ up to quantitative yield (Scheme 4 ). In a similar manner, the cyanides 7 were prepared from the bromides 3 . Treatment of the bromides $3 \mathbf{c}-\mathbf{e}$ with $\mathrm{KCN}$ in $\mathrm{EtOH} / \mathrm{H}_{2} \mathrm{O}$ at $110^{\circ} \mathrm{C}$ for $12 \mathrm{~h}$ leads to the cyanides $\mathbf{7 c}-\mathbf{e}$ in 72 to $97 \%$ yield.

Since the yields of $\mathbf{3 b}$ were limited due to side reactions like elimination, the respective cyanide $\mathbf{7 b}$ was prepared by deprotonation of hydroxy derivative 8 with $\mathrm{NaH}$ in DMF for $40 \mathrm{~min}$ at $0{ }^{\circ} \mathrm{C}$ followed by addition of 1-bromo-3-propionitrile at room temperature. After $12 \mathrm{~h}$, the cyanide $7 \mathbf{b}$ was obtained in $33 \%$ yield.

Mesomorphic properties: Mesomorphic properties of compounds 3-10 were investigated by differential scanning calorimetry (DSC), polarizing optical microscopy (POM) and X-ray diffraction (WAXS and SAXS). The DSC results for bromides $\mathbf{3}$ are summarized in Table 1.

Whereas compounds 3a,c,e with even chain lengths of the spacer displayed monotropic SmA phases, compounds 3b,d with odd chain lengths displayed enantiotropic SmA phases. A typical DSC curve of derivative 3d with a pentyloxy spacer is shown in Figure 1.

On the third heating a melting transition at $40{ }^{\circ} \mathrm{C}$ into the $\mathrm{SmA}$ phase and a clearing transition at $57{ }^{\circ} \mathrm{C}$ could be observed. Subsequent cooling revealed an isotropic to SmA transition at $60{ }^{\circ} \mathrm{C}$ and a crystallization peak at $24^{\circ} \mathrm{C}$. The SmA to crystalline transition tends to strong supercooling in the order of 10-30 $\mathrm{K}$ (Table 1, Figure 1).

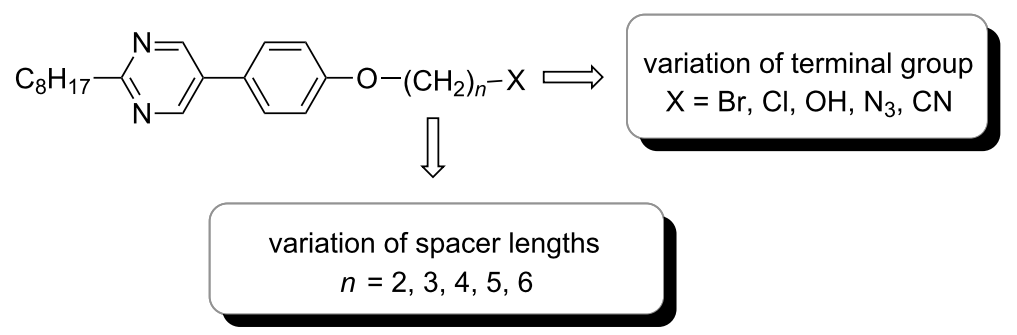

\begin{tabular}{ccc|}
\hline compd. & $n$ & $\mathrm{X}$ \\
\hline $\mathbf{3 a}-\mathbf{e}$ & $2-6$ & $\mathrm{Br}$ \\
$\mathbf{4 a - e}$ & $2-6$ & $\mathrm{Cl}$ \\
$\mathbf{5 d}, \mathbf{e}$ & 5,6 & $\mathrm{OH}$ \\
$\mathbf{6 a}-\mathbf{e}$ & $2-6$ & $\mathrm{~N}_{3}$ \\
$\mathbf{7 b}-\mathbf{e}$ & $3-6$ & $\mathrm{CN}$ \\
\hline
\end{tabular}

Scheme 2: Variation of spacer lengths and terminal group at 5-phenylpyrimidine. 
A: 1) $\mathrm{KOH}, \mathrm{DMSO}, \mathrm{rt}, 10 \mathrm{~min}$<smiles>Oc1ccc(-c2cnc([In+]c3ccccc3)nc2)cc1</smiles>

2) $\mathrm{Nu}, \mathrm{rt}, 4 \mathrm{~h}$

B: $\mathrm{K}_{2} \mathrm{CO}_{3}, \mathrm{MeCN}, \mathrm{Nu}$ reflux, $12 \mathrm{~h}$

\begin{tabular}{cccccc}
\hline method & compd. & $\mathrm{Nu}^{\mathrm{a}}$ & $n$ & $\mathrm{X}$ & yield (\%) \\
\hline B & 3a & $\mathrm{Br}\left(\mathrm{CH}_{2}\right)_{2} \mathrm{Br}$ & 2 & $\mathrm{Br}$ & 39 \\
A & 3b & $\mathrm{Br}\left(\mathrm{CH}_{2}\right)_{3} \mathrm{Br}$ & 3 & $\mathrm{Br}$ & $23^{\mathrm{b}}$ \\
A & 3c & $\mathrm{Br}\left(\mathrm{CH}_{2}\right)_{4} \mathrm{Br}$ & 4 & $\mathrm{Br}$ & 53 \\
A & 3d & $\mathrm{Br}\left(\mathrm{CH}_{2}\right)_{5} \mathrm{Br}$ & 5 & $\mathrm{Br}$ & 53 \\
A & 3e & $\mathrm{Br}\left(\mathrm{CH}_{2}\right)_{6} \mathrm{Br}$ & 6 & $\mathrm{Br}$ & 60 \\
A & 4a & $\mathrm{Cl}\left(\mathrm{CH}_{2}\right)_{2} \mathrm{Cl}$ & 2 & $\mathrm{Cl}$ & 31 \\
A & 4b & $\mathrm{Cl}\left(\mathrm{CH}_{2}\right)_{3} \mathrm{Cl}$ & 3 & $\mathrm{Cl}$ & 49 \\
A & 4c & $\mathrm{Cl}\left(\mathrm{CH}_{2}\right)_{4} \mathrm{Cl}$ & 4 & $\mathrm{Cl}$ & 70 \\
A & 4d & $\mathrm{Cl}\left(\mathrm{CH}_{2}\right)_{5} \mathrm{Cl}$ & 5 & $\mathrm{Cl}$ & 31 \\
A & 4e & $\mathrm{Cl}\left(\mathrm{CH}_{2}\right)_{6} \mathrm{Cl}$ & 6 & $\mathrm{Cl}$ & 60 \\
A & 5d & $\mathrm{Cl}\left(\mathrm{CH}_{2}\right)_{5} \mathrm{OH}$ & 5 & $\mathrm{OH}$ & 76 \\
A & 5e & $\mathrm{Cl}\left(\mathrm{CH}_{2}\right)_{6} \mathrm{OH}$ & 6 & $\mathrm{OH}$ & 80 \\
\hline
\end{tabular}

aNu: nucleophile

bbyproduct with $\mathbf{3 b}$ :
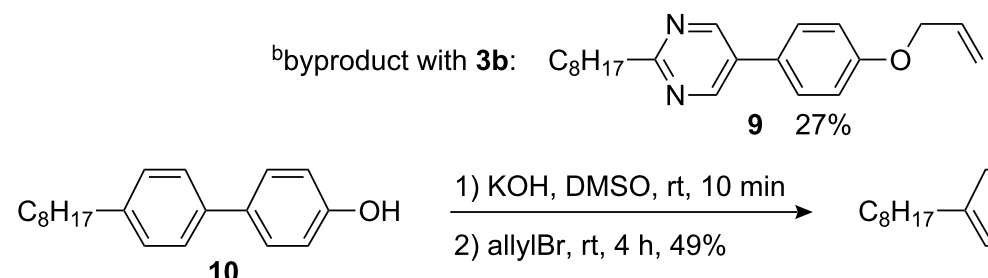

$\underset{\text { 2) allylBr, rt, } 4 \text { h, } 49 \%}{\stackrel{\mathrm{KOH}, \mathrm{DMSO}}{\mathrm{r}}}$

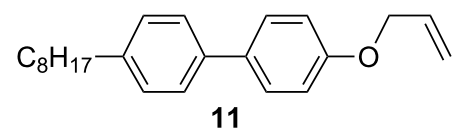

Scheme 3: Synthesis of compounds 3-5, 9 and 11.

POM observation of $\mathbf{3 a}-\mathbf{e}$ revealed fan-shaped textures typical of SmA phases. An illustrative example is depicted in Figure 2. The assignment of the SmA mesophases was further confirmed by XRD experiments (see the Supporting Information).

It should be noted that the allyloxy-substituted byproduct 9 showed a smectic mesophase between $50{ }^{\circ} \mathrm{C}$ and $67^{\circ} \mathrm{C}$ as well. In contrast, the corresponding 4-allyloxy-4'-octylbiphenyl 11 showed only isotropic melting at $92{ }^{\circ} \mathrm{C}$. The DSC results of chlorides 4 are summarized in Table 2 .

All members 4a-e showed enantiotropic SmA phases. For compounds $\mathbf{4 a , c , e}$ with even numbered spacer lengths smaller mesophase widths were observed as compared to compounds $\mathbf{4 b , \mathbf { d }}$ with odd numbered spacer lengths. Furthermore an odd-even effect of both melting and clearing points was found. A typical DSC curve which is shown in Figure 3 for chloride $4 \mathbf{e}$ with hexyloxy spacer, revealed a melting transition at $59^{\circ} \mathrm{C}$ to the smectic A phase and a clearing transition at $66{ }^{\circ} \mathrm{C}$ upon a second heating. Upon the second cooling run an isotropic to SmA transition at $64{ }^{\circ} \mathrm{C}$ and a crystallization peak at $42{ }^{\circ} \mathrm{C}$ were observed.

POM investigation displayed fan-shaped and focal conic textures, as exemplified in Figure 4. XRD experiments proved the smectic phase.

In contrast to the bromides 3 and chlorides $\mathbf{4}$, the hydroxy and azide derivatives $\mathbf{5 a}, \mathbf{b}$ and $\mathbf{7 b}-\mathbf{b}$ were non mesomorphic and showed only melting transitions at $76^{\circ} \mathrm{C}$ and $75{ }^{\circ} \mathrm{C}$ for compounds $5 \mathbf{a}$,b and at $77^{\circ} \mathrm{C}, 86^{\circ} \mathrm{C}, 67^{\circ} \mathrm{C}$ and $68^{\circ} \mathrm{C}$ for the azides $7 \mathbf{b}-\mathbf{e}$, respectively (upon heating or cooling) in the DSC curve. Presumably, the higher polarity of the terminal hydroxy group with respect to the azido group, together with hydrogen bonding, inhibits mesophase formation. Next the azides 6 were investigated by DSC (Table 3). 


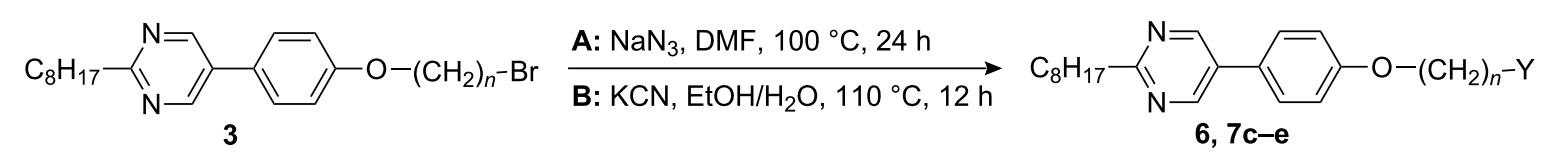

\begin{tabular}{ccccc}
\hline method & compd. & $n$ & $\mathrm{Y}$ & yield (\%) \\
\hline A & $\mathbf{6 a}$ & 2 & $\mathrm{~N}_{3}$ & 74 \\
A & $\mathbf{6 b}$ & 3 & $\mathrm{~N}_{3}$ & quant. \\
A & $\mathbf{6 c}$ & 4 & $\mathrm{~N}_{3}$ & quant. \\
A & $\mathbf{6 d}$ & 5 & $\mathrm{~N}_{3}$ & quant. \\
A & $\mathbf{6 e}$ & 6 & $\mathrm{~N}_{3}$ & quant. \\
C & $\mathbf{7 b}$ & 3 & $\mathrm{CN}$ & 33 \\
B & $\mathbf{7 c}$ & 4 & $\mathrm{CN}$ & 97 \\
B & $\mathbf{7 d}$ & 5 & $\mathrm{CN}$ & 88 \\
B & $\mathbf{7 e}$ & 6 & $\mathrm{CN}$ & 72 \\
\hline
\end{tabular}

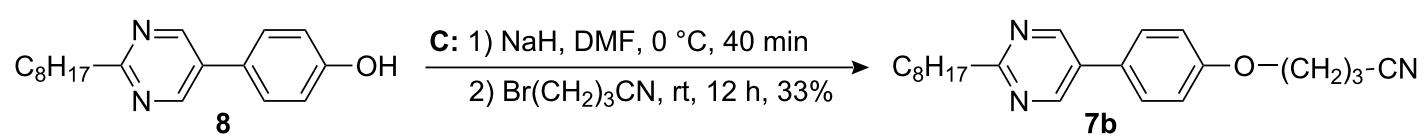

Scheme 4: Synthesis of compounds 6 and 7.

\begin{tabular}{|c|c|c|c|c|c|c|c|c|c|c|c|c|}
\hline 3 & $n$ & $\mathrm{Cr}_{1}$ & $T$ & $\Delta H$ & $\mathrm{Cr}_{2}$ & $T$ & $\Delta H$ & SmA & $T$ & $\Delta H$ & I & \\
\hline \multirow[t]{2}{*}{$\mathbf{a}$} & 2 & • & 52 & 3.9 & • & 63 & 32.2 & - & - & - & • & 2. heating \\
\hline & & - & 29 & -25.8 & - & - & - & • & 56 & -5.6 & • & 2. cooling \\
\hline \multirow[t]{2}{*}{ b } & 3 & - & 46 & 13.0 & - & - & - & - & 52 & 1.9 & • & 2. heating \\
\hline & & - & 35 & -13.9 & - & - & - & - & 52 & -3.2 & • & 2. cooling \\
\hline \multirow[t]{2}{*}{ C } & 4 & • & 66 & 31.1 & - & - & - & - & - & - & • & 2. heating \\
\hline & & - & 49 & -24.1 & - & - & - & • & 63 & -5.0 & • & 2. cooling \\
\hline \multirow[t]{2}{*}{ d } & 5 & • & 40 & 17.6 & - & - & - & - & 57 & 5.1 & • & 2. heating \\
\hline & & - & 24 & -16.7 & - & - & - & • & 60 & -5.3 & • & 2. cooling \\
\hline \multirow[t]{2}{*}{ e } & 6 & - & 64 & 36.3 & - & - & - & - & - & - & • & 2. heating \\
\hline & & • & 35 & -23.9 & - & - & - & • & 58 & -5.5 & • & 2. cooling \\
\hline
\end{tabular}

${ }^{\mathrm{a}} \mathrm{Cr}$ crystalline; SmA smectic A; I isotropic; • phase was observed; - phase was not observed. Heating and cooling rate: $10 \mathrm{~K} / \mathrm{min}$.

Whereas compound 6a with an ethoxy spacer was non mesomorphic, enantiotropic SmA phases were detected for all other chain lengths $\mathbf{6 b}-\mathbf{e}$. Compound $\mathbf{6 d}$ showed an additional crystal to crystal transition. A typical DSC curve of derivative $\mathbf{6 c}$ is shown in Figure 5. POM revealed fan-shaped and focal conic texture, see for example Figure 6. Figure 7 and Figure 8 reveal that due to substantial supercooling for all spacer chain lengths and terminal groups the mesophases are smaller during the heating cycle as compared to the cooling cycle. The broadest mesophase was observed for the azide derivative $6 \mathbf{d}$ with $\Delta T=$ $27^{\circ} \mathrm{C}$ upon heating and $\Delta T=45^{\circ} \mathrm{C}$ upon cooling. In comparison to the compounds with an azide as terminal group the halides $(n=2,5,6)$ have a lower tendency to supercooling. Whereas for azides 6 the broadest mesophase was observed for $\mathrm{C}_{5}$ spacer (6d), for chlorides $\mathbf{4}$ derivatives $\mathbf{4 b}$ and $\mathbf{4 d}$ with $\mathrm{C}_{3}$ and $\mathrm{C}_{5}$ spacer displayed similar mesophase width. For bromides $\mathbf{3}$ again the derivative $\mathbf{3 d}$ with $\mathrm{C}_{5}$ spacer showed the broadest mesophase.

From the X-ray data, the following model (Figure 9) of the layer structure is proposed. The $d$ values obtained from the $\mathrm{X}$-ray experiments fit with the molecular lengths derived from simple molecular modelling (Chem3D) [13]. For example, the XRD pattern of the azide derivative $\mathbf{6 c}$ results in a layer dis- 


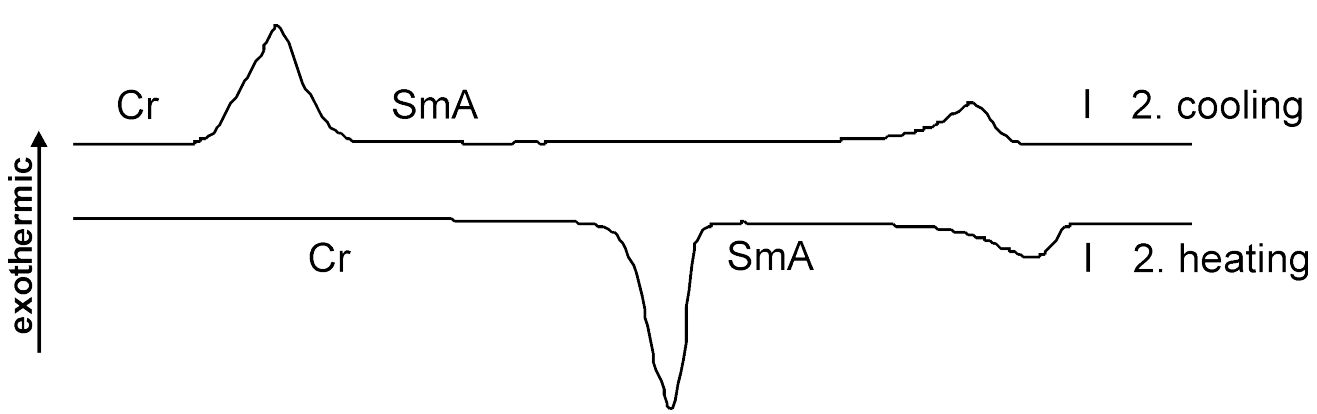

\begin{tabular}{rrrrrr}
\hline 20 & 30 & 40 & 50 & 60 & 70 \\
& & $\mathrm{~T} /{ }^{\circ} \mathrm{C}$ & &
\end{tabular}

Figure 1: DSC curve of compound $\mathbf{3 d}$ (heating/cooling rate $10 \mathrm{~K} / \mathrm{min}$ ).

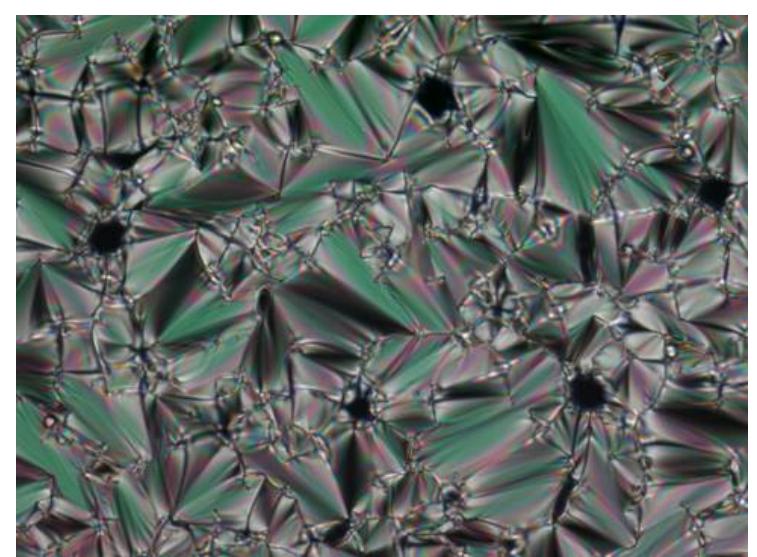

Figure 2: Fan-shaped texture of $\mathbf{3 e}$ under crossed polarizers upon cooling from the isotropic liquid (magnification 200x): at $55^{\circ} \mathrm{C}$ (cooling rate $5 \mathrm{~K} / \mathrm{min}$ ): smectic $A$ phase. tance of $25.5 \AA$, whereas the calculated length of the molecule for the most elongated conformation is $26 \AA$, which is clear evidence for the presence of monolayers. This leads to the assumption that the molecules might be aligned antiparallel within each smectic layer (Figure 9). Packing the molecules in this array prevents close contacts between the polar regions of the rigid core and the terminal groups. The observed maximum phase width for the $\mathrm{C}_{5}$ spacer regardless of the terminal group suggests that for this chain length space filling is optimal and the terminal group $\mathrm{X}$ can be accommodated well between the alkyl chains. This model might also explain why the mesophase is lost with strongly polar or hydrogen bonding terminal groups such as cyanides and hydroxy derivatives.

\section{Conclusion}

It has been shown that 5-phenylpyrimidine derivatives with terminal chloro-, bromo-, azido-, hydroxy- and cyano groups

Table 2: Phase transition temperatures $\left[{ }^{\circ} \mathrm{C}\right]$ and enthalpies $[\mathrm{kJ} / \mathrm{mol}]$ of compounds $4 .^{\mathrm{a}}$

\begin{tabular}{|c|c|c|c|c|c|c|c|c|c|}
\hline 4 & $n$ & $\mathrm{Cr}$ & $T$ & $\Delta H$ & SmA & $T$ & $\Delta H$ & I & \\
\hline \multirow[t]{2}{*}{$\mathbf{a}$} & 2 & • & 50 & 21.6 & • & 55 & 1.4 & • & 2. heating \\
\hline & & • & 25 & -18.7 & - & 53 & -1.5 & • & 2. cooling \\
\hline \multirow[t]{2}{*}{ b } & 3 & - & 37 & 11.9 & • & 53 & 3.9 & • & 2. heating \\
\hline & & • & 23 & -11.8 & • & 58 & -4.2 & • & 2. cooling \\
\hline \multirow[t]{2}{*}{ c } & 4 & - & 63 & 21.9 & • & 67 & 2.7 & • & 2. heating \\
\hline & & • & 46 & -23.5 & - & 70 & -4.9 & • & 2. cooling \\
\hline \multirow[t]{2}{*}{ d } & 5 & - & 42 & 15.7 & • & 56 & 5.0 & • & 2. heating \\
\hline & & • & 27 & -17.0 & • & 62 & -4.8 & • & 2. cooling \\
\hline \multirow[t]{2}{*}{$\mathbf{e}$} & 6 & - & 55 & 20.8 & • & 59 & 4.7 & • & 2. heating \\
\hline & & - & 42 & -25.3 & - & 64 & -4.5 & • & 2. cooling \\
\hline
\end{tabular}

${ }^{a} \mathrm{Cr}$ crystalline; SmA smectic A; I isotropic; • phase was observed; - phase was not observed. Heating and cooling rate: $10 \mathrm{~K} / \mathrm{min}$ for $\mathbf{4 a - d} 5 \mathrm{~K} / \mathrm{min}$ for $4 \mathrm{e}$. 


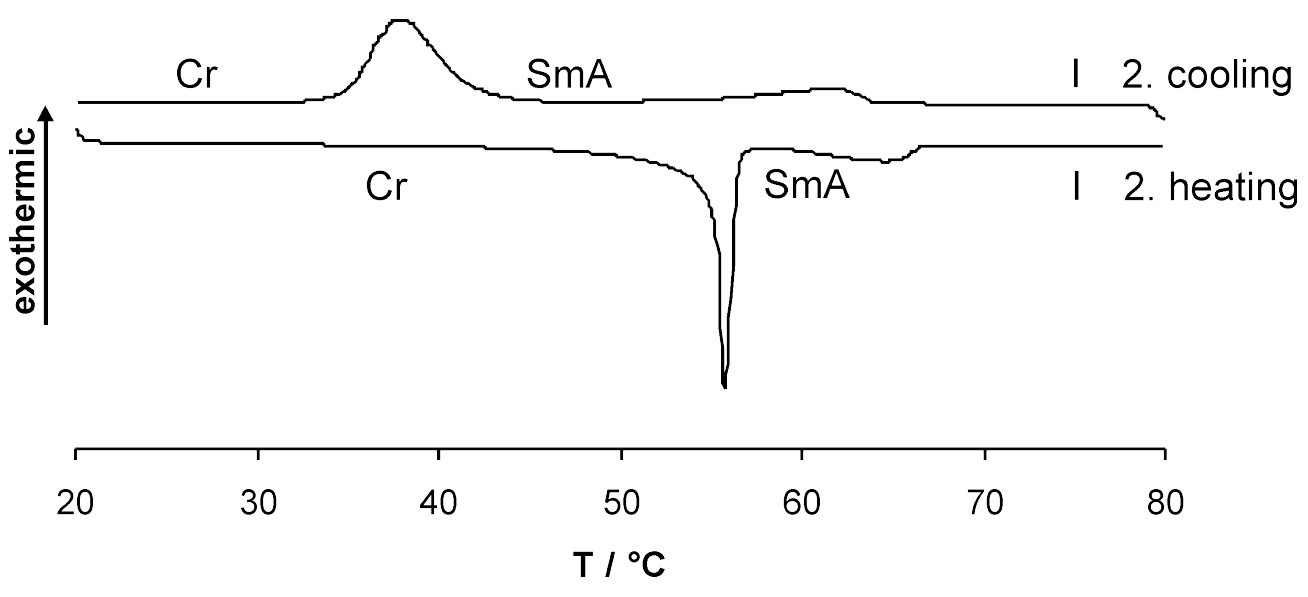

Figure 3: DSC curve of compound $4 \mathrm{e}$ (heating/cooling rate $5 \mathrm{~K} / \mathrm{min}$ ).

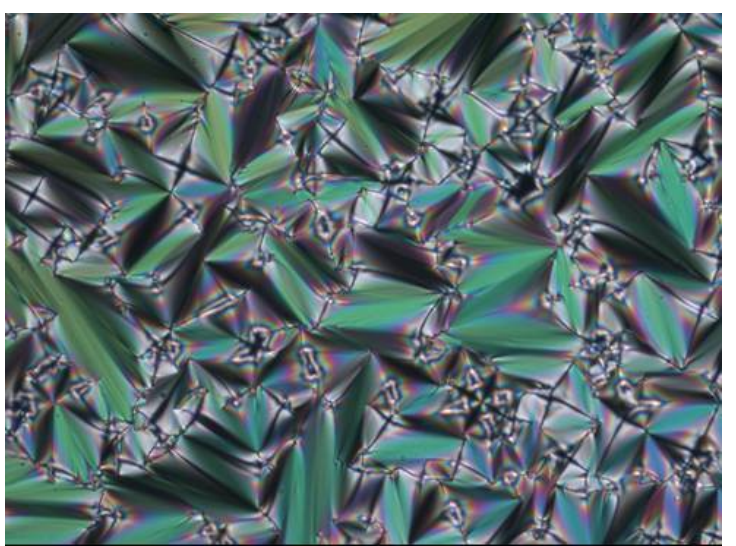

Figure 4: Fan-shaped texture of compound $4 \mathrm{~d}$ at $45^{\circ} \mathrm{C}$ upon cooling from the isotropic liquid (cooling rate $1 \mathrm{~K} / \mathrm{min}$ ) (magnification $200 \times$ ). separated by an alkoxy spacer chain from the aromatic core were easily synthesised by nucleophilic substitution. Depending on the terminal group and the tether lengths the formation of smectic A mesophases was observed for the chloro-, bromoand azido derivatives. Surprisingly, the strong latent dipole moment of hydroxy and cyano derivatives and the ability of hydroxy derivatives to form hydrogen bonds seems to completely suppress the formation of mesophases. Furthermore, the polar pyrimidine ring seems to play an important role in promoting liquid crystalline properties.

\section{Experimental}

\section{General}

Melting points were measured on a Mettler Toledo DSC822 and are uncorrected. NMR spectra were recorded on a Bruker Avance 300 and Avance 500 spectrometer. FT-IR spectra were recorded on a Bruker Vektor22 spectrometer with MKII Golden

Table 3: Phase transition temperatures $\left[{ }^{\circ} \mathrm{C}\right]$ and enthalpies $[\mathrm{kJ} / \mathrm{mol}]$ of compounds $6 .^{a}$

\begin{tabular}{|c|c|c|c|c|c|c|c|c|c|c|c|c|}
\hline 6 & $n$ & $\mathrm{Cr}_{1}$ & $T$ & $\Delta H$ & $\mathrm{Cr}_{2}$ & $T$ & $\Delta H$ & SmA & $T$ & $\Delta H$ & I & \\
\hline \multirow[t]{2}{*}{$\mathbf{a}$} & 2 & - & 48 & 30.6 & - & - & - & - & - & - & • & 2. heating \\
\hline & & • & 44 & -31.4 & - & - & - & - & - & - & • & 2. cooling \\
\hline \multirow[t]{2}{*}{ b } & 3 & - & 45 & 11.9 & - & - & - & - & 49 & 1.1 & - & 2. heating \\
\hline & & - & 34 & -13.7 & - & - & - & - & 47 & -2.9 & • & 2. cooling \\
\hline \multirow[t]{2}{*}{ c } & 4 & • & 42 & 25.3 & - & - & - & • & 60 & 5.0 & • & 2. heating \\
\hline & & • & 28 & -17.8 & - & - & - & • & 63 & -5.3 & • & 2. cooling \\
\hline \multirow[t]{2}{*}{ d } & 5 & - & 7 & 0.9 & • & 28 & 17.2 & - & 55 & 3.4 & - & 2. heating \\
\hline & & - & 1 & -0.6 & • & 11 & -16.0 & - & 57 & -4.7 & • & 2. cooling \\
\hline \multirow[t]{2}{*}{ e } & 6 & • & 41 & 26.5 & - & - & - & - & 53 & 6.1 & • & 2. heating \\
\hline & & - & 20 & -22.2 & • & 25 & -0.5 & - & 58 & -5.9 & - & 2. cooling \\
\hline
\end{tabular}

${ }^{a} \mathrm{Cr}$ crystalline; SmA smectic A; I isotropic; • phase was observed; - phase was not observed. Heating and cooling rate: $10 \mathrm{~K} / \mathrm{min}$. 


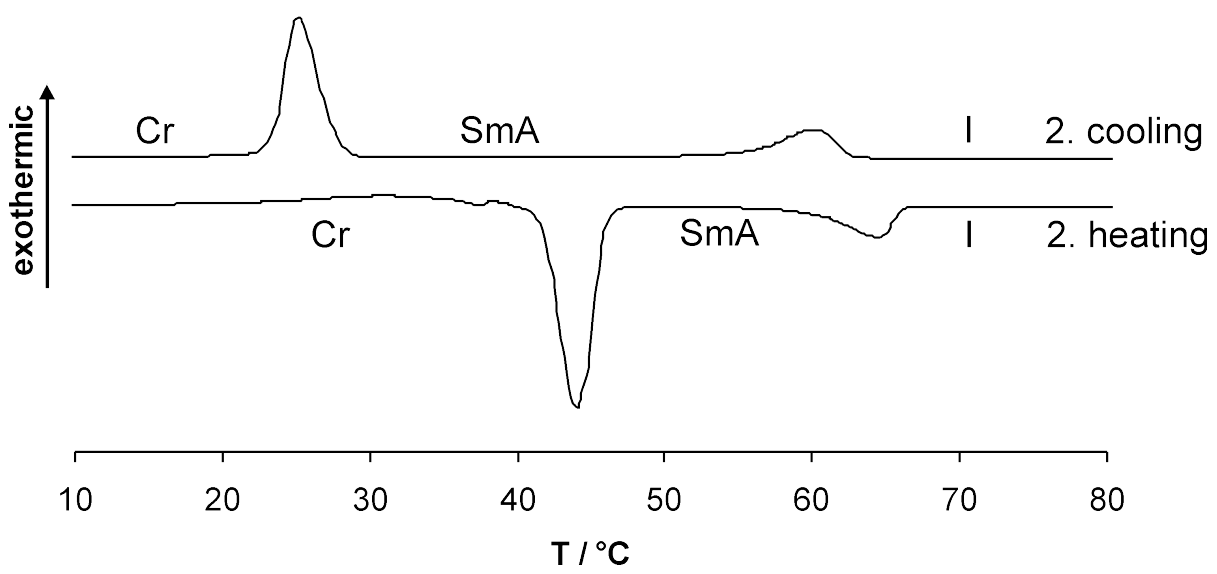

Figure 5: DSC curve of compound $\mathbf{6 c}$ (heating/cooling rate $10 \mathrm{~K} / \mathrm{min}$ ).

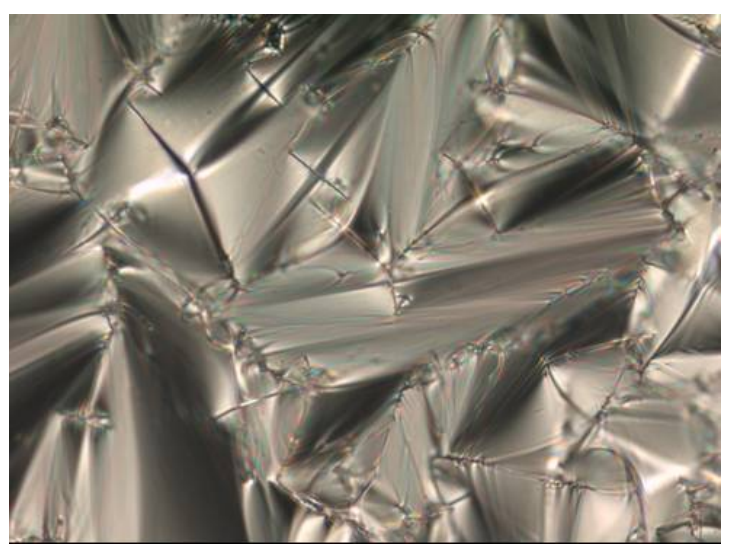

Figure 6: Fan-shaped texture of compound $6 \mathrm{e}$ at $45^{\circ} \mathrm{C}$ upon cooling from the isotropic liquid (cooling rate $10 \mathrm{~K} / \mathrm{min}$ ) (magnification 200x).
Gate Single Reflection Diamant ATR system. Mass spectra were recorded on a Finnigan MAT 95 and a Varian MAT 711 apparatus. X-Ray powder experiments were performed on a Bruker Nanostar; software: SAXS 4.1.26. The samples were kept in Hilgenberg glass capillaries of $0.7 \mathrm{~mm}$ outside diameter in a temperature-controlled heating stage $\left( \pm 1^{\circ} \mathrm{C}\right)$. A monochromatic $\mathrm{Cu}-\mathrm{K}_{\alpha} 1$ beam $(\lambda=1.5405 \AA)$ was obtained using a ceramic tube generator $(1500 \mathrm{~W})$ with cross-coupled Göbelmirrors as the monochromator. The diffraction patterns were recorded on a real-time 2D-detector (HI-STAR, Bruker). The calibration of the patterns occurred with the powder pattern of Ag-Behenate. Differential scanning calorimetry (DSC) was performed using a Mettler Toledo DSC822, and polarizing optical microscopy (POM) using an Olympus BX50 polarizing microscope combined with a Linkam LTS350 hot stage and a Linkam TP93 central processor. Flash chromatography was

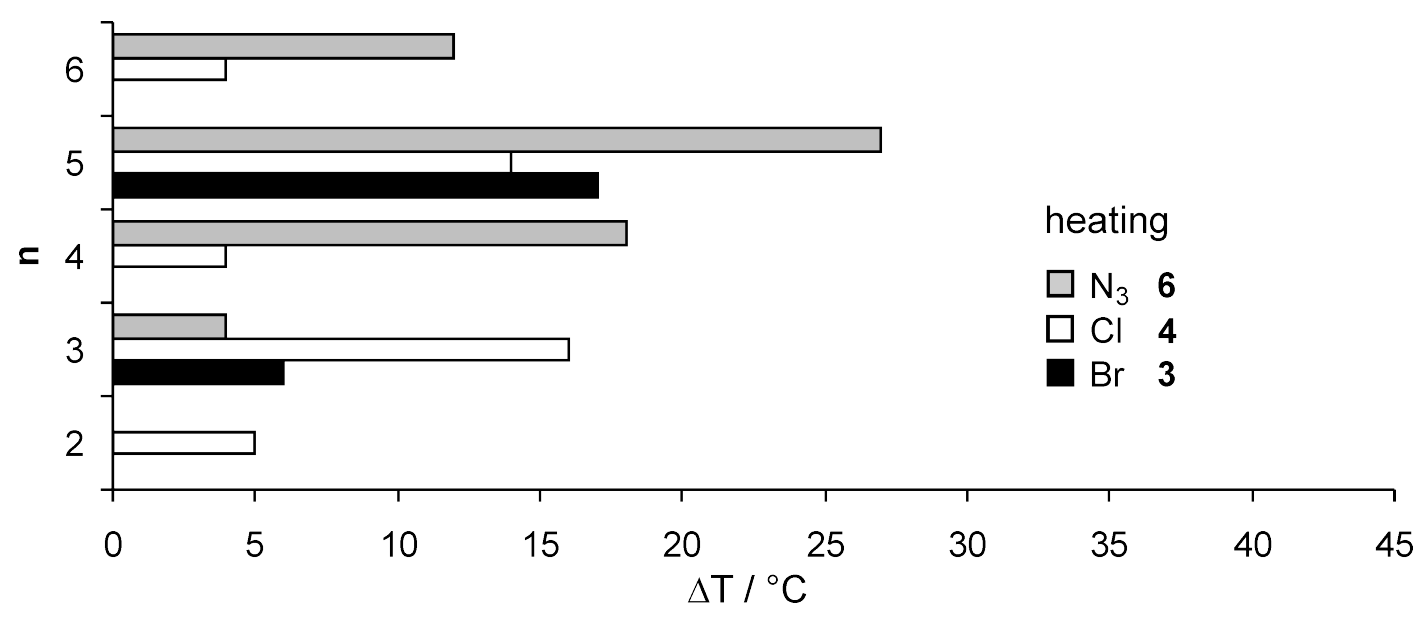

Figure 7: Comparison of the mesophase range $\Delta T$ for the different spacer lengths of compounds 3,4 and 6 : mesophase range upon heating (heating rate $10 \mathrm{~K} / \mathrm{min})$. 


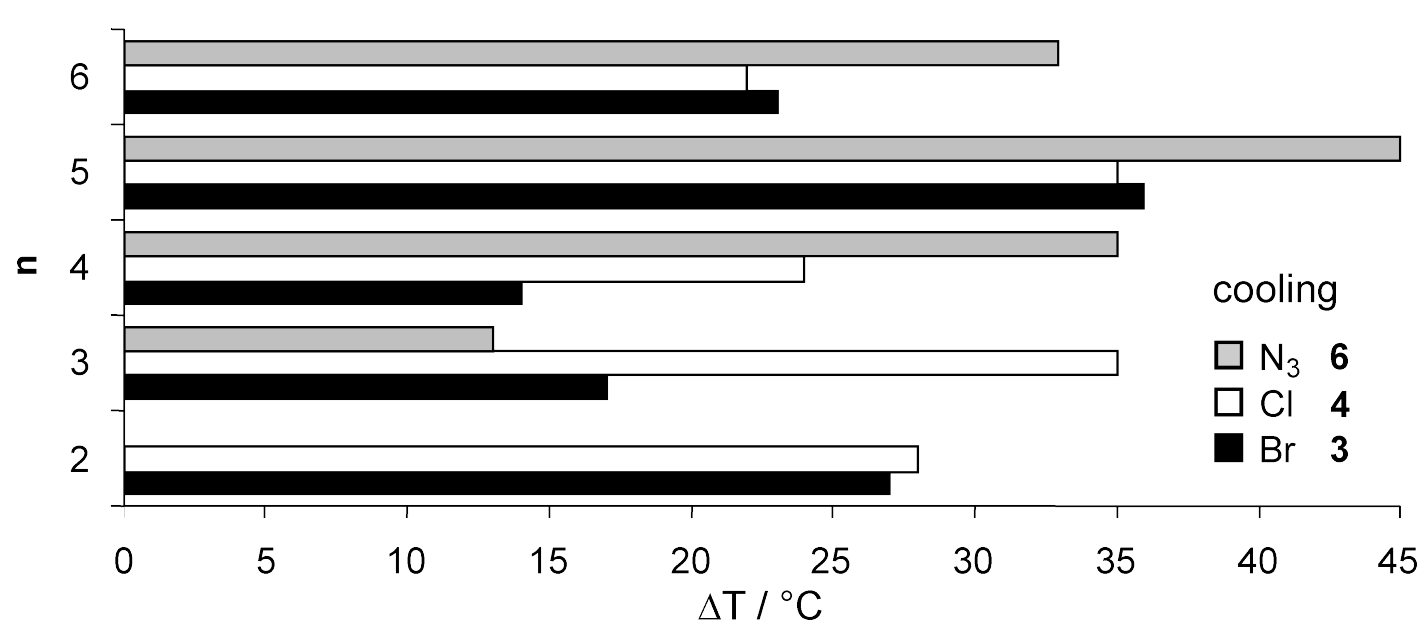

Figure 8: Comparison of the mesophase range $\Delta T$ for the different spacer lengths of compounds 3,4 and 6 : mesophase range upon cooling (cooling rate $10 \mathrm{~K} / \mathrm{min}$ ).

performed using Kieselgel 60, 40-63 $\mu \mathrm{m}$ (Fluka). All solvents were dried, and reactions were performed in dried glassware. The used petroleum ether (PE) had a boiling range of $30-75^{\circ} \mathrm{C}$.

\section{General procedure 1}

To a solution of 5-(4-hydroxyphenyl)-2-octylpyrimidine $\mathbf{8}$ ( $852 \mathrm{mg}, 3.00 \mathrm{mmol}$ ) in $4 \mathrm{~mL}$ DMSO was added powdered $\mathrm{KOH}(504 \mathrm{mg}, 9.00 \mathrm{mmol})$. After stirring for $10 \mathrm{~min}$ at room temperature, the $\alpha, \omega$-dihaloalkane (or $\alpha$-bromo- $\omega$-alkanol respectively) (3.00 mmol) was added. Stirring was continued for $4 \mathrm{~h}$ followed by quenching with $20 \mathrm{~mL} \mathrm{H} \mathrm{H}_{2} \mathrm{O}$ and $100 \mathrm{~mL}$ $\mathrm{CH}_{2} \mathrm{Cl}_{2}$. The organic layer was dried $\left(\mathrm{Na}_{2} \mathrm{SO}_{4}\right)$ and the solvents were evaporated. Finally the crude product was purified by flash chromatography.

\section{General procedure 2}

A solution of bromide $3(0.50 \mathrm{mmol})$ and $\mathrm{NaN}_{3}(81.0 \mathrm{mg}$, $1.25 \mathrm{mmol}$ ) in $15 \mathrm{~mL} \mathrm{DMF}$ was stirred at $100{ }^{\circ} \mathrm{C}$ for $24 \mathrm{~h}$. After cooling to room temperature, the reaction mixture was treated with $20 \mathrm{~mL} \mathrm{H}_{2} \mathrm{O}$ and extracted with $\mathrm{CH}_{2} \mathrm{Cl}_{2}(3 \times 30 \mathrm{~mL})$. The combined organic layers were dried $\left(\mathrm{Na}_{2} \mathrm{SO}_{4}\right)$, the solvent was evaporated and the crude product purified by flash chromatography.

\section{General procedure 3}

A solution of bromide $3(0.50 \mathrm{mmol})$ and $\mathrm{KCN}(35.8 \mathrm{mg}$, $0.55 \mathrm{mmol})$ in $4 \mathrm{~mL} \mathrm{EtOH} / \mathrm{H}_{2} \mathrm{O}(3: 1, \mathrm{v} / \mathrm{v})$ was stirred at $110^{\circ} \mathrm{C}$ for $12 \mathrm{~h}$. After cooling to room temperature, $10 \mathrm{~mL} \mathrm{CH}_{2} \mathrm{Cl}_{2}$ were added and the aqueous layer was extracted with $\mathrm{CH}_{2} \mathrm{Cl}_{2}$ $(3 \times 10 \mathrm{~mL})$. The combined organic layers were washed with $1 \mathrm{~N} \mathrm{NaOH}(1 \times 10 \mathrm{~mL})$ and dried $\left(\mathrm{Na}_{2} \mathrm{SO}_{4}\right)$. Finally the solvent was evaporated and the crude product purified by flash chromatography.

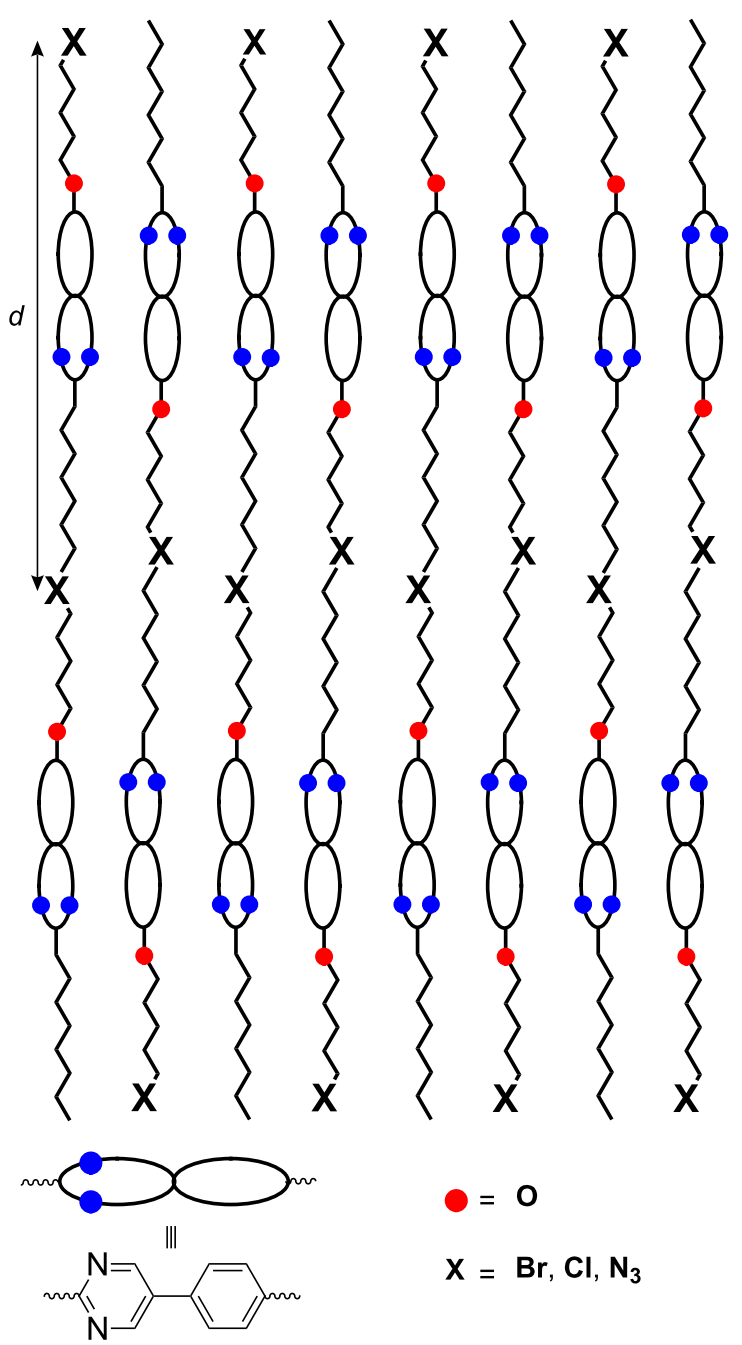

Figure 9: Proposed model for the layer structure. 


\section{5-[4-(6-Bromohexyloxy)phenyl]-2- octylpyrimidine (3e)}

Prepared according to general procedure (1). Experiment: $284 \mathrm{mg}$ (1.00 mmol) 5-(4-hydroxyphenyl)-2-octylpyrimidine 8 , $160 \mu \mathrm{L}$ (245 mg, $1.00 \mathrm{mmol})$ 1,6-dibromohexane, $168 \mathrm{mg}$ (3.00 mmol) KOH. Flash chromatography (PE/EtOAc, 4:1, v/v; $\left.R_{\mathrm{f}}=0.86: \mathrm{PE} / \mathrm{EtOAc}, 1: 1, \mathrm{v} / \mathrm{v}\right)$ gave $268 \mathrm{mg}(0.60 \mathrm{mmol}, 60 \%)$ of $3 \mathbf{e}$ as a colourless crystalline solid. DSC: $\mathrm{Cr} 35^{\circ} \mathrm{C}[-23.9 \mathrm{~kJ} /$ $\mathrm{mol}]\left(\mathrm{SmA} 58{ }^{\circ} \mathrm{C}[-5.5 \mathrm{~kJ} / \mathrm{mol}]\right)$ I. ${ }^{1} \mathrm{H} \mathrm{NMR}(300 \mathrm{MHz}$, $\left.\mathrm{CDCl}_{3}\right): \delta=0.88\left(\mathrm{t}, 3 \mathrm{H} J=6.9 \mathrm{~Hz}, \mathrm{CH}_{3}\right), 1.21-1.45(\mathrm{~m}, 10 \mathrm{H}$, $\left.\mathrm{CH}_{2}\right), 1.49-1.58\left(\mathrm{~m}, 4 \mathrm{H}, \mathrm{CH}_{2}\right), 1.79-1.98\left(\mathrm{~m}, 6 \mathrm{H}, \mathrm{CH}_{2}\right)$, 2.96-3.01 (m, 2H, 2- $\left.\mathrm{CH}_{2}\right), 3.44$ (t, $\left.2 \mathrm{H}, J=6.6 \mathrm{~Hz}, \mathrm{CH}_{2} \mathrm{Br}\right)$, $4.02\left(\mathrm{t}, 2 \mathrm{H}, J=6.4 \mathrm{~Hz}, \mathrm{OCH}_{2}\right), 6.99-7.03\left(\mathrm{~m}, 2 \mathrm{H}, 3^{\prime}-\mathrm{H}, 5^{\prime}-\mathrm{H}\right)$, 7.46-7.50 (m, 2H, 2'-H, 6'-H), 8.83 (s, 2H, 4-H, 6-H) ppm. ${ }^{13} \mathrm{C}$ NMR (125 MHz, $\left.\mathrm{CDCl}_{3}\right): \delta=14.1\left(\mathrm{CH}_{3}\right), 22.7,25.3,27.9$, 28.9, 29.0, 29.2, 29.4, 31.9, 32.7, $33.8\left(\mathrm{CH}_{2}\right), 39.2\left(2-\mathrm{CH}_{2}\right)$, $67.9\left(\mathrm{OCH}_{2}\right), 115.2\left(\mathrm{C}-3^{\prime}, \mathrm{C}-5^{\prime}\right), 128.0\left(\mathrm{C}-2^{\prime}, \mathrm{C}-6^{\prime}\right), 126.7$, 130.8 (C-1', C-5), 154.8 (C-4, C-6), 159.9 (C-4'), 169.5 (C-2) ppm. FT-IR (ATR): $\widetilde{v}=2916(\mathrm{~m}), 2848(\mathrm{~m}), 1586(\mathrm{~m}), 1536$ (m), $1515(\mathrm{~m}), 1445(\mathrm{~s}), 1247(\mathrm{~s}), 1180(\mathrm{~m}), 1116(\mathrm{~m}), 1011$ (m), $994(\mathrm{~m}), 838(\mathrm{~s}), 651(\mathrm{~m}), 608(\mathrm{~m}) \mathrm{cm}^{-1}$. MS (EI, 70eV): $m / z(\%)=446.1(100)[\mathrm{M}]^{+}, 361.0(20)\left[\mathrm{M}-\mathrm{C}_{6} \mathrm{H}_{13}\right]^{+}, 348.0$ (78) $\left[\mathrm{M}+\mathrm{H}-\mathrm{C}_{7} \mathrm{H}_{15}\right], 199.0$ (10) 186.0 (28). $\mathrm{C}_{24} \mathrm{H}_{35} \mathrm{BrN}_{2} \mathrm{O}$ (447.45): calcd. C 64.42, H 7.88, N 6.26, Br 17.86; found C 64.46, H 7.88, N 6.14, Br 17.61.

\section{5-[4-(6-Chlorohexyloxy)phenyl]-2- octylpyrimidine (4e)}

Prepared according to general procedure (1). Experiment: $85.0 \mathrm{mg}$ (0.30 mmol) 5-(4-hydroxyphenyl)-2-octylpyrimidine $\mathbf{8}$, $45.0 \mu \mathrm{L}$ (47.0 mg, $0.30 \mathrm{mmol}$ ) 1,6-dichlorohexane, $50.0 \mathrm{mg}$ $(0.90 \mathrm{mmol}) \mathrm{KOH}$. Flash chromatography (PE/EtOAc, 5:1, v/v; $\left.R_{\mathrm{f}}=0.40: \mathrm{PE} / \mathrm{EtOAc}, 3: 1, \mathrm{v} / \mathrm{v}\right)$ gave $74.0 \mathrm{mg}(0.18 \mathrm{mmol}, 60 \%)$ of $4 \mathbf{e}$ as a colourless crystalline solid. DSC: $\mathrm{Cr} 42{ }^{\circ} \mathrm{C}[-25.3 \mathrm{~kJ} /$ $\mathrm{mol}] \mathrm{SmA} 64{ }^{\circ} \mathrm{C}[-4.5 \mathrm{~kJ} / \mathrm{mol}] \mathrm{I} .{ }^{1} \mathrm{H} \mathrm{NMR}\left(300 \mathrm{MHz}, \mathrm{CDCl}_{3}\right)$ : $\delta=0.85-0.90\left(\mathrm{~m}, 3 \mathrm{H}, \mathrm{CH}_{3}\right), 1.23-1.44\left(\mathrm{~m}, 10 \mathrm{H}, \mathrm{CH}_{2}\right)$, 1.50-1.55 (m, 4H, $\left.\mathrm{CH}_{2}\right), 1.78-1.90\left(\mathrm{~m}, 6 \mathrm{H}, \mathrm{CH}_{2}\right), 2.96-3.01$ $\left(\mathrm{m}, 2 \mathrm{H}, 2-\mathrm{CH}_{2}\right), 3.56\left(\mathrm{t}, 2 \mathrm{H}, J=6.7 \mathrm{~Hz}, \mathrm{CH}_{2} \mathrm{Cl}\right), 4.01(\mathrm{t}, 2 \mathrm{H}, J$ $\left.=6.4 \mathrm{~Hz}, \mathrm{OCH}_{2}\right), 6.99-7.04\left(\mathrm{~m}, 2 \mathrm{H}, 3^{\prime}-\mathrm{H}, 5^{\prime}-\mathrm{H}\right), 7.46-7.51(\mathrm{~m}$, $\left.2 \mathrm{H}, 2^{\prime}-\mathrm{H}, 66^{\prime}-\mathrm{H}\right), 8.83$ (s, 2H, 4-H, 6-H) ppm. ${ }^{13} \mathrm{C}$ NMR $\left(75 \mathrm{MHz}, \mathrm{CDCl}_{3}\right): \delta=14.1\left(\mathrm{CH}_{3}\right), 22.7,25.4,26.6,28.8,29.1$, 29.2, 29.4, 31.9, $32.5\left(\mathrm{CH}_{2}\right), 39.2\left(2-\mathrm{CH}_{2}\right), 45.0\left(\mathrm{CH}_{2} \mathrm{Cl}\right), 67.9$ $\left(\mathrm{OCH}_{2}\right), 115.3\left(\mathrm{C}-3^{\prime}, \mathrm{C}-5^{\prime}\right), 127.9$ (C-2', C-6'), 126.7, 130.8 (C-1', C-5), 154.5 (C-4, C-6), 159.6 (C-4'), 169.6 (C-2) ppm. FT-IR (ATR): $\widetilde{v}=2917(\mathrm{~m}), 2849(\mathrm{~m}), 1587(\mathrm{~m}), 1516(\mathrm{~m})$, $1446(\mathrm{~s}), 1392(\mathrm{~m}), 1287(\mathrm{~m}), 1246(\mathrm{~s}), 1181(\mathrm{~m}), 1116(\mathrm{~m})$, $1029(\mathrm{~m}), 994(\mathrm{~m}), 941(\mathrm{~m}), 838(\mathrm{~m}), 721(\mathrm{~m}) \mathrm{cm}^{-1}$. MS (ESI): $m / z=403.3[\mathrm{M}+\mathrm{H}]^{+}, 367.3[\mathrm{M}-\mathrm{Cl}]^{+} . \mathrm{C}_{24} \mathrm{H}_{35} \mathrm{ClN}_{2} \mathrm{O}(403.00)$ : calcd. C 71.53, H 8.75, N 6.95, Cl 8.80; found C 71.38, H 8.63, N 6.81, Cl 8.93.

\section{5-[4-(6-Hydroxyhexyloxy)phenyl]-2- octylpyrimidine (5e)}

Prepared according to general procedure (1). Experiment: $568 \mathrm{mg}$ (2.00 mmol) 5-(4-hydroxyphenyl)-2-octylpyrimidine $\mathbf{8}$, $270 \mu \mathrm{L}$ (362 mg, $2.00 \mathrm{mmol}$ ) 6-bromohexane-1-ol, $336 \mathrm{mg}$ $(6.00 \mathrm{mmol}) \mathrm{KOH}$. Flash chromatography (PE/EtOAc, 1:1, v/v; $\left.R_{\mathrm{f}}=0.29\right)$ gave $615 \mathrm{mg}(1.60 \mathrm{mmol}, 80 \%)$ of $\mathbf{5 e}$ as a colourless crystalline solid. Mp: $75{ }^{\circ} \mathrm{C} .{ }^{1} \mathrm{H}$ NMR $\left(300 \mathrm{MHz}, \mathrm{CDCl}_{3}\right): \delta=$ 0.85-0.90 (m, 3H, $\left.\mathrm{CH}_{3}\right), 1.24-1.68\left(\mathrm{~m}, 16 \mathrm{H}, \mathrm{CH}_{2}\right), 1.79-1.90$ $\left(\mathrm{m}, 4 \mathrm{H}, \mathrm{CH}_{2}\right), 2.96-3.01\left(\mathrm{~m}, 2 \mathrm{H}, 2-\mathrm{CH}_{2}\right), 3.68(\mathrm{t}, 2 \mathrm{H}, J=$ $\left.6.5 \mathrm{~Hz}, \mathrm{CH}_{2} \mathrm{OH}\right), 4.01\left(\mathrm{t}, 2 \mathrm{H}, J=6.5 \mathrm{~Hz}, \mathrm{OCH}_{2}\right), 6.99-7.04(\mathrm{~m}$, $\left.2 \mathrm{H}, 3^{\prime}-\mathrm{H}, 5^{\prime}-\mathrm{H}\right), 7.46-7.51\left(\mathrm{~m}, 2 \mathrm{H}, 2^{\prime}-\mathrm{H}, 6^{\prime}-\mathrm{H}\right), 8.83$ (s, 2H, 4-H, 6-H) ppm. $\left.{ }^{13} \mathrm{C} \mathrm{NMR} \mathrm{(75} \mathrm{MHz,} \mathrm{CDCl}_{3}\right): \delta=14.1\left(\mathrm{CH}_{3}\right)$, $22.7,25.6,25.9,28.9,29.2,29.5,31.9,32.7\left(\mathrm{CH}_{2}\right), 39.2$ $\left(2-\mathrm{CH}_{2}\right), 62.8\left(\mathrm{CH}_{2} \mathrm{OH}\right), 68.0\left(\mathrm{OCH}_{2}\right), 115.3\left(\mathrm{C}-3^{\prime}, \mathrm{C}-5^{\prime}\right), 127.9$ (C-2', C-6'), 126.6, 130.8 (C-1', C-5), 154.5 (C-4, C-6), 159.7 (C-4'), 169.6 (C-2) ppm. FT-IR (ATR): $\widetilde{v}=3303$ (m, br), 2917 (s), $2848(\mathrm{~m}), 1606(\mathrm{~m}), 1586(\mathrm{~m}), 1536(\mathrm{~m}), 1516(\mathrm{~m}), 1466$ (m), $1445(\mathrm{~s}), 1377(\mathrm{~m}), 1291(\mathrm{~m}), 1288(\mathrm{~m}), 1248(\mathrm{~s}), 1181$ (m), $1118(\mathrm{~m}), 1060(\mathrm{~m}), 1007$ (m), $994(\mathrm{~m}), 918(\mathrm{~m}), 838(\mathrm{~s})$, $707(\mathrm{~m}), 652(\mathrm{~m}) \mathrm{cm}^{-1}$. MS (EI, 70eV): $m / z(\%)=384.3(100)$ $[\mathrm{M}]^{+}, 299.2$ (36), 286.2 (94). HRMS (ESI): $m / z[\mathrm{M}+\mathrm{H}]^{+}$calcd. for $\mathrm{C}_{24} \mathrm{H}_{37} \mathrm{~N}_{2} \mathrm{O}_{2}$ : 385.2850; found: 385.2856. $\mathrm{C}_{24} \mathrm{H}_{36} \mathrm{~N}_{2} \mathrm{O}_{2}$ (384.55): calcd. C 74.96, H 9.44, N 7.28; found C 75.05, H $9.27, \mathrm{~N} 7.26$.

\section{5-[4-(6-Azidohexyloxy)phenyl]-2- octylpyrimidine (6e)}

Prepared according to general procedure (2). Experiment: $224 \mathrm{mg}(0.50 \mathrm{mmol}))$ bromide $3 \mathrm{e}, 81.0 \mathrm{mg}(1.25 \mathrm{mmol}) \mathrm{NaN}_{3}$. Flash chromatography (PE/EtOAc, $\left.2: 1, \mathrm{v} / \mathrm{v} ; R_{\mathrm{f}}=0.56\right)$ gave $205 \mathrm{mg}$ ( $0.50 \mathrm{mmol}$, quant.) of $\mathbf{6 e}$ as a colourless crystalline solid. DSC: $\mathrm{Cr}_{1} 20^{\circ} \mathrm{C}[-22.2 \mathrm{~kJ} / \mathrm{mol}] \mathrm{Cr}_{2} 25^{\circ} \mathrm{C}[-0.5 \mathrm{~kJ} / \mathrm{mol}]$ SmA $58{ }^{\circ} \mathrm{C}[-5.9 \mathrm{~kJ} / \mathrm{mol}] \mathrm{I} .{ }^{1} \mathrm{H}$ NMR $\left(300 \mathrm{MHz}, \mathrm{CDCl}_{3}\right): \delta=$ 0.85-0.90 (m, 3H, CH 3$), 1.24-1.58\left(\mathrm{~m}, 14 \mathrm{H}, \mathrm{CH}_{2}\right), 1.60-1.71$ $\left(\mathrm{m}, 2 \mathrm{H}, \mathrm{CH}_{2}\right), 1.78-1.91\left(\mathrm{~m}, 4 \mathrm{H}, \mathrm{CH}_{2}\right), 2.97-3.01(\mathrm{~m}, 2 \mathrm{H}$, $\left.2-\mathrm{CH}_{2}\right), 3.30\left(\mathrm{t}, 2 \mathrm{H}, J=6.8 \mathrm{~Hz}, \mathrm{CH}_{2} \mathrm{~N}_{3}\right), 4.02$ (t, $2 \mathrm{H}, J=6.4$ $\left.\mathrm{Hz}, \mathrm{OCH}_{2}\right), 7.00-7.04\left(\mathrm{~m}, 2 \mathrm{H}, 3^{\prime}-\mathrm{H}, 5^{\prime}-\mathrm{H}\right), 7.47-7.51(\mathrm{~m}, 2 \mathrm{H}$, $\left.2^{\prime}-\mathrm{H}, 66^{\prime}-\mathrm{H}\right), 8.83$ (s, 2H, 4-H, 6-H) ppm. ${ }^{13} \mathrm{C} \mathrm{NMR}(75 \mathrm{MHz}$, $\left.\mathrm{CDCl}_{3}\right): \delta=14.1\left(\mathrm{CH}_{3}\right), 22.7,25.7,26.5,28.8,28.9,29.1,29.2$, 29.5, $31.9\left(\mathrm{CH}_{2}\right), 39.2\left(2-\mathrm{CH}_{2}\right), 51.4\left(\mathrm{CH}_{2} \mathrm{~N}_{3}\right), 67.9\left(\mathrm{OCH}_{2}\right)$, 115.3 (C-3', C-5'), 127.9 (C-2', C-6'), 126.7, 130.8 (C-1', C-5), 154.5 (C-4, C-6), 159.6 (C-4'), 169.6 (C-2) ppm. FT-IR (ATR): $\widetilde{v}=2921(\mathrm{~s}), 2847(\mathrm{~m}), 2091(\mathrm{~s}), 1605(\mathrm{~m}), 1587(\mathrm{~m}), 1467$ (m), $1446(\mathrm{~s}), 1287(\mathrm{~m}), 1246(\mathrm{~s}), 1182(\mathrm{~m}), 1032(\mathrm{~m}), 993(\mathrm{~m})$, $836(\mathrm{~s}), 654(\mathrm{~m}) \mathrm{cm}^{-1}$. MS (ESI): $m / z=432.3[\mathrm{M}+\mathrm{Na}]^{+}, 410.3$ $[\mathrm{M}+\mathrm{H}]^{+} . \mathrm{C}_{24} \mathrm{H}_{35} \mathrm{~N}_{5} \mathrm{O}(409.58)$ : calcd. C 70.38, H 8.61, N 17.10; found $\mathrm{C} 70.51, \mathrm{H} 8.55, \mathrm{~N} 17.05$. 


\section{5-[4-(6-Cyanohexyloxy)phenyl]-2- octylpyrimidine (7e)}

Prepared according to general procedure (3). Experiment: $224 \mathrm{mg}(0.50 \mathrm{mmol})$ bromide 3e, $36.0 \mathrm{mg}(0.55 \mathrm{mmol}) \mathrm{KCN}$. Flash chromatography (PE/EtOAc, $\left.4: 1, \mathrm{v} / \mathrm{v} ; R_{\mathrm{f}}=0.23\right)$ gave $142 \mathrm{mg}(0.36 \mathrm{mmol}, 72 \%)$ of $7 \mathrm{e}$ as a colourless crystalline solid. Mp: $68{ }^{\circ} \mathrm{C} .{ }^{1} \mathrm{H}$ NMR $\left(500 \mathrm{MHz}, \mathrm{CDCl}_{3}\right): \delta=0.88(\mathrm{t}, 3 \mathrm{H}$ $\left.J=6.9 \mathrm{~Hz}, \mathrm{CH}_{3}\right), 1.20-1.45\left(\mathrm{~m}, 10 \mathrm{H}, \mathrm{CH}_{2}\right), 1.51-1.60$ (m, 4H, $\left.\mathrm{CH}_{2}\right), 1.68-1.90\left(\mathrm{~m}, 6 \mathrm{H}, \mathrm{CH}_{2}\right), 2.37(\mathrm{t}, 2 \mathrm{H}, J=7.3 \mathrm{~Hz}$, $\left.\mathrm{CH}_{2} \mathrm{CN}\right), 2.96-3.01\left(\mathrm{~m}, 2 \mathrm{H}, 2-\mathrm{CH}_{2}\right), 4.02(\mathrm{t}, 2 \mathrm{H}, J=6.3 \mathrm{~Hz}$, $\left.\mathrm{OCH}_{2}\right), 6.99-7.03$ (m, 2H, 3'-H, 5'-H), 7.46-7.51 (m, 2H, 2'-H, $\left.6^{\prime}-\mathrm{H}\right), 8.81$ (s, 2H, 4-H, 6-H) ppm. ${ }^{13} \mathrm{C}$ NMR (125 MHz, $\left.\mathrm{CDCl}_{3}\right): \delta=14.1\left(\mathrm{CH}_{3}\right), 17.1,22.7,25.3,25.4,28.4,28.9,29.2$, 29.5, $31.9\left(\mathrm{CH}_{2}\right), 39.2\left(2-\mathrm{CH}_{2}\right), 67.9\left(\mathrm{OCH}_{2}\right), 115.4\left(\mathrm{C}-3^{\prime}\right.$, C-5'), 119.7 (CN), 128.0 (C-2', C-6'), 126.9, 130.8 (C-1', C-5), 154.5 (C-4, C-6), 159.6 (C-4'), 169.7 (C-2) ppm. FT-IR (ATR): $\widetilde{v}=3035(\mathrm{w}), 2950(\mathrm{~m}), 2920(\mathrm{~m}), 2852(\mathrm{~m}), 1608(\mathrm{~m}) 1588$ (m), $1541(\mathrm{~m}), 1518(\mathrm{~m}), 1440(\mathrm{~s}), 1397(\mathrm{~m}), 1245(\mathrm{~s}), 1188(\mathrm{~s})$, $1048(\mathrm{~m}), 996(\mathrm{~m}), 836(\mathrm{~s}), 738(\mathrm{~m}), 706(\mathrm{~m}), 652(\mathrm{~m}), 556(\mathrm{~m})$ $\mathrm{cm}^{-1}$. MS (EI, 70eV): $\mathrm{m} / z(\%)=393.2(72)[\mathrm{M}]^{+}, 350.2(8)$, 308.2 (28), 395.2 (100), 185.1 (11). HRMS (ESI): $\mathrm{m} / z[\mathrm{M}+\mathrm{H}]^{+}$ calcd. for $\mathrm{C}_{25} \mathrm{H}_{36} \mathrm{~N}_{3} \mathrm{O}$ : 394.2853; found: 394.2854. $\mathrm{C}_{25} \mathrm{H}_{35} \mathrm{~N}_{3} \mathrm{O}$ (393.56): calcd. C 76.29, H 8.96, N 10.68; found C 76.15, H 8.93, N 10.51.

\section{Supporting Information}

Supporting information includes experimental and spectroscopic data for compounds $4 \mathbf{a}-\mathbf{d}, \mathbf{5 d}, \mathbf{6 a}-\mathbf{d}, \mathbf{7 a}-\mathbf{d}, \mathbf{9}$, 11 and X-ray diffraction data.

\section{Supporting Information File 1}

Analytical data of compounds $4 \mathbf{a}-\mathbf{d}, \mathbf{5 d}, \mathbf{6 a}-\mathbf{d}, \mathbf{7 a}-\mathbf{d}, \mathbf{9}, 11$. [http://www.beilstein-journals.org/bjoc/content/ supplementary/1860-5397-5-63-S1.pdf]

\section{Acknowledgments}

Generous financial support by the Deutsche Forschungsgemeinschaft, the Ministerium für Wissenschaft, Forschung und Kunst des Landes Baden-Württemberg (Landesgraduierten fellowship for Elisabeth Kapatsina), the Bundesministerium für Bildung und Forschung and the Fonds der Chemischen Industrie is gratefully acknowledged.

\section{References}

1. Goodby, J. W. In Handbook of Liquid Crystals; Demus, D.; Goodby, J. W.; Gray, G. W.; Spiess, H.-W.; Vill, V., Eds.; Wiley-VCH: Weinheim, Germany, 1998; Vol. 2A, pp 411-440.

2. Adamo, C.; Barone, V. J. Chem. Phys. 1998, 108, 664-675. doi:10.1063/1.475428
3. Barone, V.; Commisso, L.; Lelj, F.; Russo, N. Tetrahedron 1985, 41, 1915-1918. doi:10.1016/S0040-4020(01)96554-8

4. Li, L.; Jones, C. D.; Magolan, J.; Lemieux, R. P. J. Mater. Chem. 2007, 17, 2313-2318. doi:10.1039/b700972k

5. Roberts, J. C.; Kapernaum, N.; Giesselmann, F.; Lemieux, R. P. J. Am. Chem. Soc. 2008, 130, 13842-13843. doi:10.1021/ja805672q

6. Neumann, B.; Hegmann, T.; Wagner, C.; Ashton, P. R.; Wolf, R.; Tschierske, C. J. Mater. Chem. 2003, 13, 778-784. doi:10.1039/b210271d

7. Kapatsina, E.; Lordon, M.; Baro, A.; Laschat, S. Synthesis 2008, 2551-2560. doi:10.1055/s-2008-1067184

8. Lloyd, D.; Reichardt, C.; Struthers, M. Liebigs Ann. Chem. 1986, 1368-1379. doi:10.1002/jlac.198619860807

9. Dox, A. W. Org. Synth. 1941, 1, 5-6.

10. Hooley, R. J.; Rebek, J. Org. Lett. 2007, 9, 1179-1182. doi:10.1021/ol062782s

11. Sugita, S.-I.; Toda, S.; Yoshiyasu, T.; Teraji, T.; Murayama, A. Mol. Cryst. Liq. Cryst. 1994, 239, 113-122. doi:10.1080/10587259408047176

12. Sugita, S.-I.; Takeno, H.; Teraji, T. Mol. Cryst. Liq. Cryst. 1991, 206, 139-146. doi:10.1080/00268949108037726

13. Chem3D Pro 2008 software was used for molecular modelling.

\section{License and Terms}

This is an Open Access article under the terms of the Creative Commons Attribution License

(http://creativecommons.org/licenses/by/2.0), which permits unrestricted use, distribution, and reproduction in any medium, provided the original work is properly cited.

The license is subject to the Beilstein Journal of Organic Chemistry terms and conditions:

(http://www.beilstein-journals.org/bjoc)

The definitive version of this article is the electronic one which can be found at: doi:10.3762/bjoc.5.63 